\title{
HFBR CONTAINMENT TEST, APRIL 9, 10, 1965
}

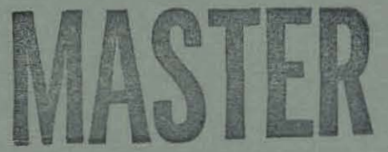

\author{
P.R. TICHLER
}

June, 1965 


\section{DISCLAIMER}

This report was prepared as an account of work sponsored by an agency of the United States Government. Neither the United States Government nor any agency Thereof, nor any of their employees, makes any warranty, express or implied, or assumes any legal liability or responsibility for the accuracy, completeness, or usefulness of any information, apparatus, product, or process disclosed, or represents that its use would not infringe privately owned rights. Reference herein to any specific commercial product, process, or service by trade name, trademark, manufacturer, or otherwise does not necessarily constitute or imply its endorsement, recommendation, or favoring by the United States Government or any agency thereof. The views and opinions of authors expressed herein do not necessarily state or reflect those of the United States Government or any agency thereof. 


\section{DISCLAIMER}

Portions of this document may be illegible in electronic image products. Images are produced from the best available original document. 
June, 1965

BROOKHAVEN NATIONAL LABORATORY

Upton, New York 


\section{SUMMARY}

Safety considerations require that the leak rate from the HFBR containment building should not exceed $5 \%$ of the building volume per day at a 2 psi overpressure. This report presents the results of a test to measure the HFBR leak rate. The test was performed on April 9-10, 1965 in accordance with the procedure described in detail in Appendix A. In brief, the test consisted of pressurizing the containment building with a blower to some initial pressure and observing the pressure decay with time.

The measured average leak rate, using the reference volume method described in Appendix B was $3.7 \pm 0.3 \% /$ day. This average leak rate, which was obtained during a period in which the overpressure varied from 2.01 to $1.36 \mathrm{psi}$, can be prorated to a leak rate at 2 psi overpressure by making the conservative assumption that the leak rate is directly proportional to the overpressure. on this basis a leak rate of $4.4 \pm 0.4 \% /$ day is obtained.

\section{MEASUREMENTS}

Copies of the data sheets are attached to this report. The variables of interest. computed from the initial and final values of the data are listed beloin:

\section{a. Building Air Temperature}

Each value given below is the average of twelve temperatures: the six dry bulb temperatures at positions $1-6$ and six temperatures at position 7-12.

Initial temperature $=\mathrm{T}_{i}=531.6^{\circ} \mathrm{R}$

Final temperature $=\mathrm{T}_{\mathrm{f}}=532.4{ }^{\circ} \mathrm{R}$

b. Reference Volume Temperature

Each value given below is the average of the six temperatures at position $A-F$.

Initial temperature $=\mathrm{T}_{r i}=533.8^{\circ} \mathrm{R}$

Final temperature $=\mathrm{T}_{\text {rf }}^{r i}=534.4{ }^{\circ} \mathrm{R}$

\section{c. Barometric Pressure}

The values given below are data sheet values corrected for temperature.

Initial barometric pressure $=B_{i}=14.63 \mathrm{psi}$

Final barometric pressure $=B_{f}^{i}=14.73$ psi 
d. Pressure Difference Between Building and Atmosphere

The values given below are data sheet values corrected for temperature.

Initial pressure difference $=\Delta \mathrm{p}_{3 i}=2.01 \mathrm{psi}$ Final pressure difference $=\Delta P_{3 f}=1.36 \mathrm{psi}$

e. Pressure Difference Between Reference Volume and Building

The values given below are data sheet values corrected for temperature.

Initial pressure difference $=\Delta \mathrm{p}_{1 i}=0.123 \mathrm{psi}$

Final pressure difference $=\Delta \mathrm{P}_{1 \mathrm{f}}=0.718 \mathrm{psi}$

f. Building Air Pressure

$$
\begin{aligned}
\text { Initial pressure }=\mathrm{p}_{i} & =\mathrm{B}_{\dot{1}}+\Delta \mathrm{p}_{3 i} \\
& =1.63+\frac{1}{2} .61 \\
& =16.64 \mathrm{psi} \\
\text { Final pressure }=\mathrm{p}_{\mathrm{f}} & =\mathrm{B}_{\mathrm{f}}+\Delta \mathrm{p}_{3 f} \\
& =14.73+1.36 \\
& =16.09 \mathrm{psi}
\end{aligned}
$$

9. Water Vapor Partial Pressure.

The partial pressure of water vapor is calculated from the wet and dry bulb temperature by means of the following empirical relationship ${ }^{*}$ which replaces the equation given in Appendix $A$ :

$$
p_{v}=p_{-N}-p \frac{\left(t_{d}-t_{w}\right)}{2700}
$$

where

$$
\begin{aligned}
& t_{d}=\text { dry bulb temperature, }{ }^{\circ} \mathrm{F} \\
& t_{w}=\text { wet bulb temperature, }{ }^{\circ} \mathrm{F} \\
& p_{w}=\text { vapor pressure corresponding to } t_{w} \\
& p^{w}=\text { total pressure }
\end{aligned}
$$

Each value listed below is an average calculated from the six wet and dry bulb temperature measurements at positions 1-6.

$$
\begin{aligned}
& \text { Initial partial pressure }=p_{v i}=0.17 \mathrm{psi} \\
& \text { Final partial pressure }=p_{v f}=0.18 \mathrm{psi}
\end{aligned}
$$

\footnotetext{
* L. S. Marks, "Mechanical Engineers'Handbook", (McGraw-Hill, New York, lýll), f'lfth Ed., p. 355.
} 


\section{ERROR ANALYSIS}

\section{a. Building Air Temperature}

Six of the twelve temperatures which make up the average building air temperature are measured with centigrade thermometers that can be read to better than $\pm 1 / 2^{\circ} \mathrm{C}$. The other six temperatures are measured with a Farhenheit thermometer than can be read to better than $\pm 1^{\circ} \mathrm{F}$. The error is taken to be $\pm 1^{\circ} \mathrm{F}$ or ${ }^{\circ} \mathrm{R}$.

\section{b. Barometric Pressure}

The barometric pressure is measured with a mercury barometer that. can be read to \pm 0.01 in. Hg. A temperature correction is then applied. The error in barometric pressure is taken to be \pm 0.01 in. $\mathrm{Hg}$. or $\pm 0.005 \mathrm{psi}$.

\section{c. Differential Pressures}

The differential pressures are measured with manometers that can be read to \pm 0.1 in. $\mathrm{H}_{2} \mathrm{O}$. A temperature correction is then applied. The error is taken to be \pm 0.1 in. $\mathrm{H}_{2} \mathrm{O}$ or \pm 0.004 . psi.

\section{d. Building Air Pressure}

The building air pressure is the sum of the barometric pressure and the pressure difference between building and atmosphere. The error is, then, the sum of the errors in barometric and differential pressure measurements which is $\pm 0.009 \mathrm{psi}$.

\section{e. Water Vapor Partial Pressure}

The equation used to calculate $p_{v}$ can be used to estimate the effect of errors in the measurement of the wet and dry bulb temperatures on $\mathrm{p}_{\mathrm{v}}$. At nominal conditions of $70^{\circ} \mathrm{F}$ dry bulb, $60^{\circ} \mathrm{F}$ wet bulb and $16.7^{\mathrm{V}} \mathrm{psi}$ total pressure, a $1^{\circ} \mathrm{F}$ error in both wet and dry bulb temperature measurements will give rise to errors in $\mathrm{p}_{\mathrm{v}}$ of 0.016 and $0.0062 \mathrm{psi}$, respectively. The error in $\mathrm{p}_{\mathrm{V}}$ is taken to be the sum of these two errors, or $\pm 0.022 \mathrm{psi}$.

Tabulated on the following page is a summary of the errors associated with each variable and its contribution to the uncertainty in the calculation of building leakage. The influence coefficients have been computed using the equations developed in Appendix $B$ and the measured values of the variables given in section 2 . 


\begin{tabular}{|c|c|c|c|}
\hline Parameter & $\begin{array}{c}\text { Influence } \\
\text { Coefficient }\end{array}$ & Error & $\begin{array}{c}\text { Contribution to Leakage } \\
\text { Uncertainty }\end{array}$ \\
\hline $\mathrm{T}_{i}$ & $1.03 \times 10^{-4}$ & $1^{\circ} \mathrm{R}$ & $1.03 \times 10^{-4}$ \\
\hline $\mathrm{T}_{\mathrm{f}}$ & $1.03 \times 10^{-4}$ & $1^{\circ} \mathrm{R}$ & $1.03 \times 10^{-4}$ \\
\hline$p_{i}$ & $2.25 \times 10^{-3}$ & $0.009 \mathrm{psi}$ & $0.20 \times 10^{-4}$ \\
\hline$p_{v i}$ & $5.85 \times 10^{-2}$ & $0.022 \mathrm{psi}$ & $12.87 \times 10^{-4}$ \\
\hline$P_{V f}$ & $6.07 \times 10^{-2}$ & $0.022 \mathrm{psi}$ & $13.35 \times 10^{-4}$ \\
\hline$\Delta \mathrm{p}_{1 \mathrm{i}}$ & $6.07 \times 10^{-2}$ & $0.004 \mathrm{psi}$ & $2.43 \times 10^{-4}$ \\
\hline$\Delta \mathrm{P}_{1 \mathrm{f}}$ & $6.07 \times 10^{-2}$ & $0.004 \mathrm{psi}$ & $2.43 \times 10^{-4}$ \\
\hline
\end{tabular}

The errors discussed above are random errors associated with the reading of the various temperature and pressure instruments. systematic errors due to inaccuracies in the instruments themselves do not add significantly to the uncertainty in the leak rate because, with one exception, these errors tend to be selfcancelling. A systematic error in the measurement of building air pressure, $p_{i}$ is not self-cancelling because only the initial value of this parameter appears in the leakage equation. However, an error in $p_{i}$, is not important because of the relatively small value of its influence coefficient.

It is worthwhile comparing the building air temperatures, $T_{i}$ and $T_{f}$, with the reference volume temperatures, $T_{r i}$ and $T_{r f}$. In the development of the equation for computing the leakage using the reference volume method, it was assumed that $\mathrm{T}_{i}=\mathrm{T}_{r i}$ and $T_{f}=T_{r f}$. Actually, the leakage equation is also valid if $T_{i} / T_{f}=T_{r i} / T_{r f}$. The measured value of these ratios are $T_{i} / T_{f}$ $=0.9985$ and $\mathrm{T}_{r i} / \mathrm{T}_{r f}=0.9989$. The difference in these ratios are so small that the resultant error in the leakage is negligible.

\section{LEAKAGE AND LEAK RATE}

The building leakage using the reference volume method is given by

$$
L=\frac{T_{i}}{T_{f}} \frac{\Delta p_{1 f}+p_{V f}}{p_{i}-p_{V i}}-\frac{\Delta p_{l i}+p_{V i}}{p_{i}-p_{v i}}
$$


$I$ is calculated to be 0.037 using the values given in section 2. The uncertainty in $L$ as determined in section 3 is \pm 0.003 . The average leak rate for the test, which lasted 24 hours, is

$$
\begin{aligned}
\bar{R} & =\frac{0.037 \pm 0.003}{24 \mathrm{hr}} \times 24 \mathrm{hr} / \mathrm{day} \\
& =0.037 \pm 0.003 \text { per day }
\end{aligned}
$$

This average leak rate should be prorated to a 2 psi overpressure. To do this it is necessary to make an assumption about the relationship between leak rate and overpressure. It is expected that the containment building has some leakage paths in which the leak rate is proportional to the first power of the overpressure and others in which the leak rate is proportional to the square root of the overpressure. In prorating to a higher pressure it is conservative to assume that the first power relationship holds. On this assumption a correction factor will be developed which can prorate an average leak rate to a leak rate at any given overpressure.

$$
\text { 1) } \begin{aligned}
r & =\mathrm{K}_{1} \Delta \mathrm{p} \\
\text { where } & \\
\mathrm{r} & =\text { leak rate } \\
\Delta \mathrm{p} & =\mathrm{p}-\mathrm{p}_{\mathrm{b}}=\text { overpressure } \\
\mathrm{p} & =\text { building air pressure } \\
\mathrm{p}_{\mathrm{b}} & =\text { barometric pressure }
\end{aligned}
$$

If we neglect temperature and humidity changes, the following relationship can be written:

$$
\text { 2) } w=k_{2} p
$$

where

$$
\mathrm{w}=\text { weight of air in building }
$$

The rate of change of $w$ with time is given by

$$
\text { 3) } \frac{d w}{d t}=-r
$$

Also, for constant barometric pressure

$$
\text { 4) } \frac{d p}{d t}=\frac{d \Delta p}{d t}
$$

Combining equations (1), (2), (3), and (4) we get

$$
\text { 5) } \frac{d \Delta p}{d t}=-K_{3} \Delta p
$$




$$
\text { where } \mathrm{K}_{3}=\frac{\mathrm{K}_{1}}{\mathrm{~K}_{2}}
$$

Equation (5) can be integrated with the known condition that

$$
\begin{aligned}
\Delta p & =\Delta p_{i} \text { at } t=t_{i} \\
\text { and } \Delta p & =\Delta p_{f} \text { at } t=t_{f}
\end{aligned}
$$

The solution is,

6) $\Delta \mathrm{p}=\Delta \mathrm{p}_{i} \exp \cdot\left|-\mathrm{K}_{3}\left(t-t_{i}\right)\right|=\Delta \mathrm{p}_{\mathrm{f}} \exp \cdot\left|-\mathrm{K}_{3}\left(t-t_{f}\right)\right|$

where

7) $\mathrm{k}_{3}=\frac{\ln \Delta \mathrm{p}_{i} / \Delta \mathrm{p}_{\mathrm{f}}}{t_{\dot{f}}-t_{i}}$

The average leak rate over the interval $t_{i}$ to $t_{f}$ is, from equations (2) and (3)
8) $\bar{r}=\frac{w_{i}-w_{f}}{t_{f}-t_{i}}=\frac{k_{2}\left(\Delta p_{i}-\Delta p_{f}\right)}{t_{f}-t_{i}}$

The instantaneous leak rate at any overpressure, $\Delta p$, is, from equations (1) and (7)

$$
\text { 9) } r=k_{1} \Delta p=k_{2} \frac{\ln \Delta p_{i} / \Delta p_{f}}{t_{f}-t_{i}} \Delta p
$$

These leak rates should be normalized to a form which is comparable to the form of the measured leak rate. The normalized average leak rate is

$$
\text { 10) } \bar{R}=\frac{\bar{r}}{p_{i}}=k_{2} \frac{\left(\Delta p_{i}-\Delta p_{f}\right)}{p_{i}\left(t_{f}-t_{i}\right)}
$$

The normalized instantaneous leak rate at overpressure $\Delta \mathrm{p}$ is

$$
\text { 11) } R=\frac{r}{p}=K_{2} \frac{\left(\ln \Delta p_{i} / \Delta p_{f}\right) \Delta p}{\left(t_{f}-t_{i}\right) p}
$$

The ratio $R / \bar{R}$ can now be formed. 
12) $\mathrm{R} / \overline{\mathrm{R}}=\mathrm{C}_{\mathrm{L}}=\frac{\left.\ln \Delta \mathrm{p}_{\mathrm{i}} / \Delta \mathrm{p}_{f}\right)\left(\mathrm{p}_{i}\right)(\Delta \mathrm{p})}{\left(\Delta \mathrm{p}_{i}-\Delta \mathrm{p}_{\mathrm{f}}\right)(\mathrm{p})}$

The leak rate at overpressure $\dot{\Delta p}$ is the measured average leak rate multiplied by $C_{I}$. An analogous factor can be derived if the assumption is made that the leak rate is proportional to the square root of the overpressure. This factor is

$$
\text { 13) } \mathrm{C}_{\mathrm{T}}=\frac{2 \sqrt{\Delta \mathrm{p}}}{\sqrt{\Delta \mathrm{p}_{i}}+\sqrt{\Delta \mathrm{p}_{f}}} \frac{\mathrm{p}_{i}}{\mathrm{p}}
$$

For the leak test discussed in this report, $\Delta p_{i}=2.01 \mathrm{psi}$, $\Delta \mathrm{p}_{f}=1.36 \mathrm{psi}, \Delta \mathrm{p}=2.00 \mathrm{psi}$ and $\mathrm{p}_{j} / \mathrm{p}=1.00$. The calculated vafues of $C_{L}$ and $C_{T}$ are 1.18 and 1.09 , respectively. The leak rate at 2 psi overpressure, using the more conservative approach is

$$
\begin{aligned}
1.18 \times(0.037 \pm 0.003) & =0.044 \pm 0.004 \text { per day } \\
& =4.4 \pm 0.4 \% / \text { day }
\end{aligned}
$$


DATA SHEET TO. 1

BUILDING LEAK TEST - MA:NOMETER READINGS

$$
\begin{aligned}
& \text { Date: } 9 \text { April, } 1965 \\
& \text { Operator: }
\end{aligned}
$$

\begin{tabular}{|c|c|c|c|c|c|c|}
\hline & Time & $\begin{array}{c}\mathrm{p}_{\mathrm{B}} \\
\text { Barometer } \\
\text { In. }\end{array}$ & $\begin{array}{l}\text { Tempera- } \\
\text { ture }{ }^{\circ} \mathrm{F}\end{array}$ & $\begin{array}{c}\Delta \mathrm{P}_{1} \\
\mathrm{In} \cdot \mathrm{H}_{2} \mathrm{O}\end{array}$ & $\begin{array}{c}\Delta \mathrm{P}_{2} \\
\mathrm{In} \cdot \mathrm{H}_{2} \mathrm{O} \\
\end{array}$ & $\begin{array}{c}\therefore \mathrm{P}_{3} \\
\text { In. } \mathrm{H}_{2} \mathrm{O} \\
\end{array}$ \\
\hline 1. & 0410 & 29.89 & 64.5 & 3.4 & 58.6 & 55.4 \\
\hline 2 & 0510 & 29.89 & 64.0 & 4.0 & 58.2 & 54.2 \\
\hline 3. & 0610 & 29.90 & 64.0 & 4.7 & 57.9 & 53.1 \\
\hline 4. & 0710 & 29.91 & 64.0 & 5.6 & 57.8 & 52.3 \\
\hline 5. & 0810 & 29.92 & 64.0 & 6.2 & 58.0 & 51.6 \\
\hline 6. & 0910 & 29.93 & 62.5 & 6.0 & 58.0 & 51.0 \\
\hline 7. & 1010 & 29.93 & 65.0 & 7.7 & 58.4 & 50.6 \\
\hline 8. & 1110 & 29.92 & 65.5 & 8.4 & 58.8 & 50.2 \\
\hline 9. & 1210 & 29.92 & 66.0 & 9.1 & 58.8 & 49.6 \\
\hline 10. & 131.0 & 29.91 & 66.0 & 9.8 & 59.2 & 49.4 \\
\hline 11. & 1410 & 29.90 & 66.1 & 10.4 & 59.6 & 49.0 \\
\hline 12. & 1510 & 29.87 & 66.1 & 11.1 & 59.7 & 48.5 \\
\hline 13. & 1610 & 29.88 & 66.8 & 11.7 & 59.6 & 47.9 \\
\hline 14. & 1710 & 29.88 & 65.6 & 12.5 & 59.4 & 46.8 \\
\hline 1.5 & 1810 & 29.88 & 66.8 & 13.1 & 59.4 & 46.1 \\
\hline 16. & 1910 & 29.91 & 67.0 & 13.9 & 58.8 & 44.6 \\
\hline 17. & 2010 & 29.93 & 66.5 & 14.6 & 58.3 & 43.5 \\
\hline 18. & 2110 & 29.93 & 66.5 & 15.3 & 58.4 & 42.8 \\
\hline 19. & 2210 & 29.93 & 66.0 & 16.0 & 58.2 & 42.0 \\
\hline 20 & 2310 & 29.95 & 66.0 & 16.7 & 58.1 & 41.2 \\
\hline 21. & 0010 & 29.97 & 65.8 & 17.3 & 57.8 & 40.3. \\
\hline 22 & 0110 & 29.97 & 65.5 & 18.0 & 57.7 & 39.5 \\
\hline 23. & 0210 & 29.98 & 65.0 & 18.6 & 57.5 & 38.8 \\
\hline 24. & 0310 & 29.98 & 65.0 & 19.2 & 57.4 & 38.0 \\
\hline 25. & 0410 & 29.99 & 65.0 & 19.8 & 57.4 & 37.4 \\
\hline
\end{tabular}

$\Lambda P_{1}$ : Pressure Difference Between Reference Volume \& Building

^P 2: Pressure Differencc Botween Reference volume \& Atmosphere

¿ $\mathrm{P}_{3}$ : Pressure Difference Between Building \& Atmosphere 
DATA SHEET NO. 2

BUILDING LEAK TES T - REFERENCE VOLUME TEMPERATURE READINGS

Date: 9 April, 1965 Operator:

\begin{tabular}{|c|c|c|c|c|c|c|}
\hline Time & $\begin{array}{c}\text { Position } \\
\mathrm{A} \\
{ }^{\circ} \mathrm{C} \\
\end{array}$ & $\begin{array}{c}\text { Position } \\
\mathrm{B} \\
{ }^{\circ} \mathrm{C} \\
\end{array}$ & $\begin{array}{c}\text { Position } \\
\mathrm{C} \\
{ }^{\circ} \mathrm{C} \\
\end{array}$ & $\begin{array}{c}\text { Position } \\
\mathrm{D} \\
{ }^{\circ} \mathrm{C} \\
\end{array}$ & $\begin{array}{c}\text { Position } \\
\mathrm{E} \\
{ }^{\circ} \mathrm{C} \\
\end{array}$ & $\begin{array}{c}\text { Position } \\
\mathrm{F} \\
{ }^{\circ} \mathrm{C} \\
\end{array}$ \\
\hline 1.0415 & 20.1 & 20.3 & 24.5 & 25.0 & 24.0 & 25.5 \\
\hline 2.0515 & 19.5 & 20.0 & 24.3 & 24.7 & 24.0 & 25.5 \\
\hline 3.0615 & 19.5 & 19.9 & 24.0 & 24.5 & 24.0 & 25.8 \\
\hline 4.0715 & 19.7 & 20.0 & 24.0 & 24.5 & 24.2 & 25.8 \\
\hline 5.0815 & 20.0 & 20.5 & 24.3 & 24.7 & 24.3 & 25.7 \\
\hline 6.0915 & 19.5 & 21.5 & 24.3 & 24.6 & 24.4 & 25.7 \\
\hline 7.1015 & 20.1 & 21.3 & 24.3 & 24.7 & 24.5 & 25.7 \\
\hline 8.1115 & 19.9 & 21.7 & 24.6 & 24.6 & 24.5 & 26.0 \\
\hline 9.1215 & 20.5 & 21.4 & 24.8 & 24.8 & 24.5 & 26.0 \\
\hline 10.1315 & 20.6 & 21.6 & 24.6 & 24.6 & 24.5 & 25.7 \\
\hline 11.1415 & 20.5 & 21.7 & 24.6 & 24.5 & 24.6 & 25.8 \\
\hline 12.1515 & 20.5 & 21.6 & 24.7 & 24.6 & 24.7 & 26.3 \\
\hline 13.1530 & 20.5 & 21.5 & 25. & 24.5 & 25. & 26.5 \\
\hline 14.1730 & 20.5 & 21.0 & 25. & 24.5 & 25. & 26.5 \\
\hline 15.1820 & 20.2 & 20.7 & 24.8 & 24.6 & 25.1 & 26.5 \\
\hline 16.1915 & 20.1 & 21. & 24.8 & 24.6 & 25.1 & 26.6 \\
\hline 17.2020 & 20.0 & 20.5 & 24.9 & 24.6 & 25.4 & 26.6 \\
\hline 18.2130 & 20.0 & 20.5 & 24.9 & 24.6 & 25.4 & 26.6 \\
\hline 19.2230 & 20. & 20.5 & 24.9 & 24.6 & 25.4 & 25.6 \\
\hline $20 . \underline{2330}$ & 20. & 20.3 & 24.7 & 24.6 & 25.4 & 26.9 \\
\hline 21.0015 & 19.8 & 20.3 & 24.7 & 24.7 & 25.3 & 26.8 \\
\hline 22.0115 & 19.8 & 20.2 & 24.7 & 24.7 & 25.3 & 26.8 \\
\hline 23.0215 & 19.8 & 20.3 & 24.7 & 24.7 & 25.3 & 26.8 \\
\hline 24.031 .5 & 19.7 & 20.3 & 24.8 & 24.7 & 25.4 & 26.9 \\
\hline 25.0415 & 19.5 & 20.1. & 24.7 & 24.7 & 25.3 & 26.9 \\
\hline
\end{tabular}

\footnotetext{
Position A: North End - Operations Level

Position B: South End - Operations Level

Position C: East End-Experimental Level

Position D: West End - Experimental Level

Position E: East End - Equipment Level

Fosition F : West End - Equipment Level.
} 
BUILDING LEAK TEST - DRY BULB \& WET BULB READINGS

Date: 9 April, 1965 Operator:

\begin{tabular}{|c|c|c|c|c|c|c|}
\hline Time & $\begin{array}{c}\text { Position } \\
\mathrm{DB} / \mathrm{WB} \\
{ }^{\circ} \mathrm{F} \\
\end{array}$ & $\begin{array}{c}\text { Position } 2 \\
\text { DB/WB } \\
{ }^{\circ} \mathrm{F}\end{array}$ & $\mid \begin{array}{c}\text { Position } 3 \\
\mathrm{DB} / \mathrm{WB} \\
{ }^{\circ} \mathrm{F}\end{array}$ & $\mid \begin{array}{c}\text { Position } \\
\mathrm{DB} / \mathrm{WB} \\
{ }^{\circ} \mathrm{F}\end{array}$ & $\begin{array}{c}\text { Position } 5 \\
\text { DB/WB } \\
{ }^{\circ} \mathrm{F} \\
\end{array}$ & $\begin{array}{c}\text { Position } 6 \\
\mathrm{DB} / \mathrm{WB} \\
\mathrm{F} \\
\end{array}$ \\
\hline 1. 0415 & $69 / 58$ & $68 / 57$ & $72 / 58$ & $73 / 58$ & $71 / 61$ & $74 / 62$ \\
\hline 2. 0515 & $68 / 59$ & $68 / 57$ & $73 / 59$ & $73 / 59$ & $74 / 61$ & $74 / 62$ \\
\hline 3. 0615 & $68 / 58$ & $67 / 56$ & $73 / 58$ & $72 / 57$ & $74 / 61$ & $73 / 62$ \\
\hline 4. 0715 & $69 / 58$ & $68 / 57$ & $72 / 58$ & $72 / 58$ & $74 / 62$ & $73 / 62$ \\
\hline 5. 0815 & $68 / 56$ & $68 / 56$ & $72 / 57$ & $72 / 58$ & $73 / 61$ & $74 / 62$ \\
\hline 6. 0915 & $70 / 58$ & $70 / 58$ & $73.5 / 59$ & $73 / 59$ & $74 / 62.5$ & $75 / 63$ \\
\hline 7. 1015 & $68 / 57$ & $69 / 57$ & $73 / 58$ & $73 / 58$ & $75 / 61$ & $74 / 62$ \\
\hline 8. 1115 & $70 / 57.5$ & $69 / 57$ & $73 / 59$ & $73 / 59$ & $74 / 62.5$ & $75 / 62.5$ \\
\hline 9. 1215 & $69 / 57$ & $69 / 57$ & $73 / 58$ & $73 / 58$ & $74 / 61.0$ & $75 / 63$ \\
\hline 10. 1315 & $70 / 58$ & $69.5 / 57$ & $73 / 59$ & $73 / 59$ & $74.5 / 63.0$ & $75.5 / 64$ \\
\hline $11 . \underline{1415}$ & $69 / 58$ & $69 / 58$ & $73 / 59$ & $73 / 59$ & $75 / 62.0$ & $75 / 63$ \\
\hline 12. 1515 & $70 / 58$ & $68.5 / 57.5$ & $73.5 / 59$ & $73.5 / 59.5$ & $74 / 62$ & $75 / 63$ \\
\hline 13. 1625 & $68 / 58$ & $68 / 56.5$ & $72.5 / 58.5$ & $72.6 / 58.6$ & $73 / 62.5$ & $76.4 / 62.5$ \\
\hline 14.1715 & $69 / 58$ & $67.2 / 57$ & $72.5 / 59.0$ & $72.0 / 59.0$ & $73.3 / 62.7$ & $74.8 / 63.0$ \\
\hline 15.1820 & $68 / 56.8$ & $67.3 / 56$ & $72 / 58.7$ & $72.7 / 58.5$ & $74.1 / 62.7$ & $74.4 / 62.7$ \\
\hline 16.1915 & $68.8 / 57.2$ & $67.8 / 56.5$ & $71.0 / 59.0$ & $72.5 / 59.0$ & $73.0 / 63.0$ & $75.0 / 63.0$ \\
\hline 17.2030 & $68 / 57$ & $69 / 57$ & $73 / 60$ & $73 / 59$ & $74 / 64$ & $74 / 63$ \\
\hline 18. 2130 & $68 / 57$ & $68 / 57$ & $73 / 59$ & $73 / 60$ & $73 / 63$ & $76 / 63$ \\
\hline 19. 2230 & $69 / 58$ & $68.5 / 58$ & $73 / 60$ & $73 / 59$ & $73 / 64$ & $76.5 / 63$ \\
\hline 20.2330 & $68 / 59$ & $68.6 / 57$ & $72.7 / 59$ & $72.7 / 58.7$ & $74.8 / 63.5$ & $75.7 / 63.5$ \\
\hline 21.0015 & $68 / 58$ & $67 / 57$ & $73 / 59$ & $72 / 59$ & $75 / 63$ & $76 / 63$ \\
\hline $22 \cdot 0115$ & $68 / 58$ & $67 / 5.7$ & $73 / 59$ & $72 / 59$ & $75 / 64$ & $75 / 63$ \\
\hline 23.0215 & $68 / 58$ & $67 / 57$ & $73 / 59$ & $73 / 59$ & $75 / 63$ & $76 / 64$ \\
\hline $4 \cdot \quad 0315$ & $67 / 58$ & $67 / 57$ & $73 / 59$ & $73 / 59$ & $75 / 63$ & $75 / 63$ \\
\hline $25 \cdot 0415$ & $67 / 58$ & $67 / 57$ & $73 / 59$ & $73 / 59$ & $75 / 63$ & $75 / 63$ \\
\hline
\end{tabular}

Position 1: East Pile Face - Operations Level

Position 2: west Pile Face - Operations Tievel

Position 3: 'East Pile Face - Experimental Level

position 4: West Pile Face - Experimental Level

Position 5: East Pile Face - Equipment Level

Position 6: West Pile Face - Equipment Level 
BUILDING LEAK TEST - CONTAINMENT VOLUME TEMPERATURE READINGS

Date: 9 April, 1965 Operator:

\begin{tabular}{|c|c|c|c|c|c|c|}
\hline Time & $\begin{array}{c}\text { Position } \\
7 \\
{ }^{\circ} \mathrm{C} \\
\end{array}$ & $\begin{array}{c}\text { Position } \\
8 \\
{ }^{\circ} \mathrm{C} \\
\end{array}$ & $\begin{array}{c}\text { Position } \\
9 \\
\circ \mathrm{C} \\
\end{array}$ & $\begin{array}{c}\text { Position } \\
10 \\
{ }^{\circ} \mathrm{C} \\
\end{array}$ & $\begin{array}{c}\text { Position } \\
11 \\
{ }^{\circ} \mathrm{C} \\
\end{array}$ & $\begin{array}{c}\text { Position } \\
12 \\
{ }^{\circ} \mathrm{C} \\
\end{array}$ \\
\hline 1.0115 & 20.3 & 19.9 & 23.0 & 23.0 & 24.0 & 23.8 \\
\hline 2. 0515 & 20.2 & 19.8 & 23.0 & 22.8 & 24.0 & 23.8 \\
\hline 3. 0615 & 20.0 & 19.6 & 23.0 & 22.8 & 23.8 & 23.8 \\
\hline 4. 0715 & 20.2 & 19.8 & 23.0 & 22.8 & 24.0 & 23.8 \\
\hline 5. 0815 & 20.5 & 20.0 & 22.8 & 22.9 & 23.8 & 23.8 \\
\hline 6. 0915 & 20.8 & 20.4 & 22.9 & 23.0 & 23.9 & 23.8 \\
\hline 7. 1015 & 20.8 & 20.5 & 22.9 & 23.0 & 24.0 & 23.8 \\
\hline 8. 1115 & 21.0 & 20.8 & 23.2 & 23.0 & 24.0 & 24.0 \\
\hline 9. 1215 & 20.8 & 20.6 & 23.1 & 23.0 & 24.1 & 24.0 \\
\hline 10. 1315 & 21.0 & 20.9 & 23.3 & 23.0 & 24.2 & 24.1 \\
\hline $11 . \quad 1415$ & 21.0 & 20.9 & 23.3 & 23.1 & 24.3 & 24.1 \\
\hline $12 . \quad 1515$ & 20.9 & 20.9 & 23.4 & 23.2 & 24.5 & 24.2 \\
\hline $13 . \quad 1615$ & 20.8 & 20.7 & 23.4 & 23.2 & 24.5 & 24.5 \\
\hline 14. 1715 & 20.8 & 20.7 & $2 \underline{3.3}$ & 23.2 & 24.5 & 24.5 \\
\hline $15 . \quad 1815$ & 20.8 & 20.5 & 23.5 & 23.2 & 24.5 & 24.5 \\
\hline 16.1915 & 20.9 & 20.5 & 23.6 & 23.4 & 23.0 & 24.8 \\
\hline 17.2015 & 20.5 & 20. & 23.5 & 23.2 & 24.8 & 24.9 \\
\hline 18. 2130 & 20.5 & 20.0 & 23.5 & 23.5 & 24.8 & 25. \\
\hline 19. 2230 & 20.5 & 20.0 & 23.5 & 23.5 & 24.9 & 24.9 \\
\hline $20 . \quad 2330$ & 20.2 & 19.8 & 23.5 & 23.3 & 25.0 & 24.9 \\
\hline 21.0015 & 20.5 & 19.8 & 23.5 & 23.2 & 25.0 & 25.0 \\
\hline 22. 0115 & 20.2 & 19.8 & 23.5 & 23.5 & 25.0 & 25.0 \\
\hline $23 \cdot \quad 0215$ & 20.2 & 19.8 & 23.6 & 23.5 & 25.0 & 25.0 \\
\hline 24.0315 & 20.2 & 19.8 & 23.5 & 23.5 & 25.0 & 25.0 \\
\hline $25 . \quad 0415$ & 20.1 & 19.7 & 23.5 & 23.4 & 25.0 & 24.9 \\
\hline
\end{tabular}

Position 7: North Stairway - Operations Level

Position 8: South Stairway - Operations Leve1

Position 9: North Stairway - Experimental Level

Position 10: South Stairway - Experimental Level

Position 11: North Stairway - Equipment Level

Position 12: South Stairway - Equipment Level 
BROOKHAVEN NATIONAL LABORATORY

\title{
MEMORANDUM
}

DATE : $\quad 11 / 4 / 64$

\author{
TO: $\quad$ File \\ FROM: L. G. Epel, W. J. Schneider \\ SUBJECT: Building Containment Test \\ Procedure
}

\section{PURPOSE}

The purpose of this test is to provide a means of determining the ability of the reactor containment to retain, within permissible leakage rates, the overpressure due to the maximum credible accident.

\section{INTRODUCTION}

The volume of the containment building including the air locks is $1.73 \times 106$ cubic feet. In the safety analysis report a leakage value of $5 \%$ at 2 psi. over-pressure was used in evaluating the effects of the M.C.A. The actual leak rate is measured by pressurizing the building with a blower, to 1 psi*, and then observing the pressure drop as a function of time within the sealed containment.

\section{DESCRIPTION OF EQUIPMENT}

The following is a list of equipment and instruments used during the tests:

1. Blower - A Buffalo forge centrifugal blower is located, with appropriate valves and piping, in the North Receiving area and is used to pressurize the building.

2. Manometers - Three differential manometers having graduations of $1 / 5$ inches of $\mathrm{H}_{2} \mathrm{O}$ are located in the North Receiving area. They can be valved to give the following readings:

a. $\Delta p_{1}=$ Difference between reference volume and containment volume.

* The building initially will be tested at both 2 psi and 1 psi. The ratio of leakage at 2 psi and at 1 psi will be used to prorate all succeeding 1 psi tests. 
b. $\Delta \mathrm{p}_{2}=$ Difference between reference volume and atmosphere.

c. $\Delta \mathrm{p}_{3}=$ Difference between containment volume and atmosphere.

3. Reference volume - This is a leak tight system constructed of 2" copper pipe with interconnecting tubing located on ail three levels of the building. The volumes of these three elements are proportional to the volume of the containment on that level.

4. Thermometers - A total of 12 Mercury thermometers having graduations of $1{ }^{\circ} \mathrm{C}$ are located at both ends of each of the reference volumes and at the North and South sides of all three levels. These are used to determine the temperature in the reference volume and building, respectively.

5. S1ing Psychrometers - Sling psychrometer readings are taken at the East and West pile faces on all three levels to determine relative humidity as well as temperatures.

6. Mercury Barometer - This barometer is located in the North Receiving area and is used to measure atmospheric pressure. A thermometer is located on this instrument so that the barometric pressure reading can be corrected for inches of $\mathrm{Hg}$ at $32^{\circ} \mathrm{F}$.

7. Strain Gauges - There are 20 strain gauges attached to the dome and four to two anchor bolts securing the dome to the pad. These gauges are read on the initial test only and are optional data thereafter.

8. Pressure-Stat - This is an additional safety device set before each test to the desired cut-off pressure and serves to interrupt the blower power supply.

\section{PROCEDURE:}

A. Preliminary - This is usually completed the day before the test takes place.

1. Check the four air lock doors to see that they are operational.

2. Purge the reference volume with dry compressed air from an air bottle. Purging is accomplished by pressurizing the system to $100 \mathrm{psi}$ four to five times and then relieving to atmosphere. The reference volume is then pressurized to 30 inches of $\mathrm{H}_{2} \mathrm{O}$ for the 1 psi test and 60 inches of $\mathrm{H}_{2} 0$ for the 2 psi test, valved closed, and allowed to remain overnight. This serves as a test of the integrity of the system. 
3. Set the pressure-stat to 1 psi ( 2 psi for the 2 psi test) on a test stand. There is a screw driver adjustment to accomplish this.

4. Check grease in the blower bearings.

B. Preparatory -- This is done just prior to the test.

1. Install thermometers at each end of the reference volumes located on the building's three levels.

2. Install thermometers on each level at the North and South stairways.

3. Check zeros on manometers and calibrate barometer located in North Receiving area. Check to see if there is any change in reference volume pressure. Secure all valves at the manometers.

4. Check the zero reading during those tests in which strain gauge readings are taken. This is mandatory for the 2 psi test, optional thereafter.

5. Insure that the four inner air lock doors are closed and seated properly.

6. Close and seat properly the two bulkhead doors and the North truck lock hatch.

7. Close inlet and outlet butterfly valves and shut down exhaust fan. This can be accomplished by tripping the nuclear incident monitor and then removing the stop on the exhaust valve so it closes fully:

8. Insure that all eight air handling units are in operation and the air conditioning is on.

9. De-energize Breaker No. 23 on Lighting Pane1 "C" on the Experimental Level. This will prevent the air compressor dryer from bleeding air into the containment building.

10. Check with Meterology to insure that there is no unusual atmospheric condition that might affect the test.

11. Procure polyethlene sheets and cover canal. 
C. Test

1. Start the building containment blower with the suction valve open and the discharge closed. With a clip-on-ammeter read the current in one of the phases to the motor. By opening the discharge, increase the motor current to 25 amperes. This is equivalent to $20 \mathrm{HP}$ and the blower is pumping $1280 \mathrm{CFM}$ at 59 inches of $\mathrm{H}_{2} \mathrm{O}$. The blower will operate $1-1 / 2$ hours to reach 1 psi.

2. As building pressure is increasing and at test pressure, check inner air lock gaskets with smoke tubes and "Leak Tec". When doors are completely checked, close the outer doors and open inner air locks for the duration of the test.

3. On those tests in which readings are taken, record strain gauge readings as the pressure is increased.

4. Stop the blower by depressing the stop button when desired pressure is reached: Approximately $27.5^{\prime \prime} \mathrm{H}_{2} \mathrm{O}$ for $1 \mathrm{psi}$ and $55^{\prime \prime}$ $\mathrm{H}_{2} \mathrm{O}$ for 2 psi. Valve the discharge and suction valves closed. Caution: It is imperative that the building not be allowed to be pressurized over 2 psi $55^{\prime \prime} \mathrm{H}_{2} 0$.

5. Record the reference volume, building and sling psychrometer temperatures on the data sheets once an hour.

6. Valve the manometers to give a differential reading as outlined below:

$\Delta \mathrm{P}_{1}$, Differential between reference volume and containment.

$\Delta \mathrm{p}_{2}$ Reference volume and atmosphere.

$\Delta \mathrm{p}_{3}$ Containment volume and atmosphere.

Record these readings on the data sheets every hour.

7. Record temperature and barometric pressure on data sheets every: hour.

8. Run the test for 24 hours.

On completion of the test depressurize by opening the exhaust butterfly up to the stop. Do not allow the differential across the filters to exceed $3^{\prime \prime}$ $\mathrm{H}_{2} \mathrm{O}$. After building pressure has dropped to $2^{\prime \prime} \mathrm{H}_{2} \mathrm{O}$, open inlet butterflies, open exhaust valve completely, start exhaust fans and reset nuclear incident monitor. 
The following are the data sheets and the formulas for determining the leak rate. The error associated with the absolute method of determining the leakage is about $1.7 \%$. Utilization of the reference volume method results in an error in lite leakage of about . $5 \%$.

Distribution:
A, B, Operators
H. Farrel1
J. Phillips
G. Pitcher 
DATE:

OPERATOR:

$$
\begin{aligned}
& \mathrm{T}_{\mathrm{i}}=\text { Initial Temperature }=\left[\mathrm{T}_{1}+\mathrm{T}_{2}+\mathrm{T}_{3}+\mathrm{T}_{4}+\mathrm{T}_{5}+\mathrm{T}_{6}+\right. \\
& \frac{9}{5}\left(\mathrm{~T}_{7}+\mathrm{T}_{8}+\mathrm{T}_{9}+\mathrm{T}_{10}+\mathrm{T}_{11}+\mathrm{T}_{12)+5712] \div 12}\right. \\
& =\quad \mathrm{O}_{\mathrm{R}} \\
& \mathrm{T}_{\mathrm{f}}=\text { Final Temperature }=\left[\mathrm{T}_{1}+\mathrm{T}_{2}+\mathrm{T}_{3}+\mathrm{T}_{4}+\mathrm{T}_{5}+\mathrm{T}_{6}+\right. \\
& \left.\frac{9}{5}\left(\mathrm{~T}_{7}+\mathrm{T}_{8}+\mathrm{T}_{9}+\mathrm{T}_{10}+\mathrm{T}_{11}+\mathrm{T}_{12}\right)+5712\right) \div 12
\end{aligned}
$$

The corrected barometric pressure (in inches $\mathrm{Hg}$ at $32^{\circ} \mathrm{F}$ ) must be used.

See for example L. S. Marks' Mechanical Engineers' Handbook, Fifth Edition, page 2067

*i*;

Where p*is the saturation pressure of water vapor at the wet bulb temperature, in psi

Trit is the wet bulb temperature, in degrees fahrenheit

$\Delta \mathrm{T}^{*} *$ is the difference between dry bulb and wet bulb temperatures, in degrees fahrenheit

al.1 taken at the beginning of the leak test

(average of 6 values from each of the 6 positions) 


$$
\mathrm{p}_{\mathrm{vf}}=\mathrm{p} *-\frac{\mathrm{p}_{\mathrm{f}}-\mathrm{p} *}{2830-1.44 \mathrm{~T} *} \quad \Delta_{\mathrm{T} *}=\quad \text { psi }
$$

Where $\mathrm{p}^{*}$ is the saturation pressure of water vapor at the wet bulb temperature, in psi

T* is the wet bulb temperature, in degrees fahrenheit

$\Delta T^{*}$ is the difference between $d r y$ bulb and wet bulb temperatures, in degrees fahrenheit

all taken at the end of the leak test

(average of 6 values from each of the 6 positions)

$\mathrm{L}_{\mathrm{a}}=$ Total Leakage (absolute method) Fractional Leakage of building volume

$$
=1-\frac{T_{i}}{T_{f}} \frac{p_{f}-p_{v f}}{p_{i}}=
$$

$\mathrm{L}_{\mathrm{r}}=$ Total Leakage (Reference volume method) Fractional Leakage of building volume

$=\frac{\mathrm{T}_{i}}{\mathrm{~T}_{\mathrm{f}}} \frac{\Delta \mathrm{p}_{f}+\mathrm{p}_{\mathrm{if}}}{\mathrm{p}_{i}-\mathrm{p}_{\mathrm{vi}}}-\frac{\Delta \mathrm{p}_{i}+\mathrm{p}_{\mathrm{vi}}}{\mathrm{p}_{i}-\mathrm{p}_{\mathrm{vi}}}=$

$$
\begin{aligned}
\mathrm{LR}_{a} & =\text { Leakage Rate (absolute method) } \\
& =2400 \mathrm{~L}_{\mathrm{a}} / \text { Duration of Test (in hours) } \\
& =\quad \% \text { per day }
\end{aligned}
$$

$$
\begin{aligned}
\mathrm{LR}_{r} & =\text { Leakage Rate (reference volume method) } \\
& =2400 \mathrm{~L}_{\mathrm{r}} / \text { Duration of Test (in hours) } \\
& =\% \text { per day }
\end{aligned}
$$


DATA SHEET NO. 1

BUILDING LEAK TEST - MANOMETER READINGS

Date:

Operator:

\begin{tabular}{|c|c|c|c|c|c|}
\hline Time & $\begin{array}{c}\mathrm{p}_{\mathrm{B}} \\
\text { Barometer } \\
\text { In. Hg. }\end{array}$ & $\begin{array}{l}\text { Tempera- } \\
\text { ture }{ }^{\circ} \mathrm{F}\end{array}$ & $\begin{array}{c}\Delta \mathrm{P}_{1} \\
\text { In. } \mathrm{H}_{2} \mathrm{O}\end{array}$ & $\begin{array}{c}\Delta \mathrm{P}_{2} \\
\text { In. } \mathrm{H}_{2} \mathrm{O} \\
\end{array}$ & $\begin{array}{c}\triangle \mathrm{P}_{3} \\
\text { In. } \mathrm{H}_{2} \mathrm{O} \\
\end{array}$ \\
\hline \multicolumn{6}{|l|}{1.} \\
\hline \multicolumn{6}{|l|}{2.} \\
\hline \multicolumn{6}{|l|}{3.} \\
\hline \multicolumn{6}{|l|}{4 . } \\
\hline \multicolumn{6}{|l|}{5.} \\
\hline \multicolumn{6}{|l|}{6.} \\
\hline \multicolumn{6}{|l|}{7.} \\
\hline \multicolumn{6}{|l|}{8.} \\
\hline 9. & & & & & - \\
\hline \multicolumn{6}{|l|}{10.} \\
\hline \multicolumn{6}{|l|}{11.} \\
\hline \multicolumn{6}{|l|}{12.} \\
\hline \multicolumn{6}{|l|}{13.} \\
\hline \multicolumn{6}{|l|}{14.} \\
\hline \multicolumn{6}{|l|}{15.} \\
\hline \multicolumn{6}{|l|}{16.} \\
\hline \multicolumn{6}{|l|}{17.} \\
\hline \multicolumn{6}{|l|}{18.} \\
\hline \multicolumn{6}{|l|}{19.} \\
\hline \multicolumn{6}{|l|}{20.} \\
\hline \multicolumn{6}{|l|}{21.} \\
\hline \multicolumn{6}{|l|}{22.} \\
\hline \multicolumn{6}{|l|}{23.} \\
\hline \multicolumn{6}{|l|}{24.} \\
\hline 25. & & & & & \\
\hline
\end{tabular}

$\Delta P_{1}$ : Pressure Difference Between Reference Volume \& Building

$\Lambda P_{2}$ : Pressure Difference Between Reference Volume \& Atmosphere

$\triangle \mathrm{P}_{3}$ : Pressure Difference Between Building \& Atmosphere 
DATA SHEET NO. 2

BUILDING LEAK TEST - REFERENCE VOLUME TEMPERATURE READINGS

Date:

Operator:

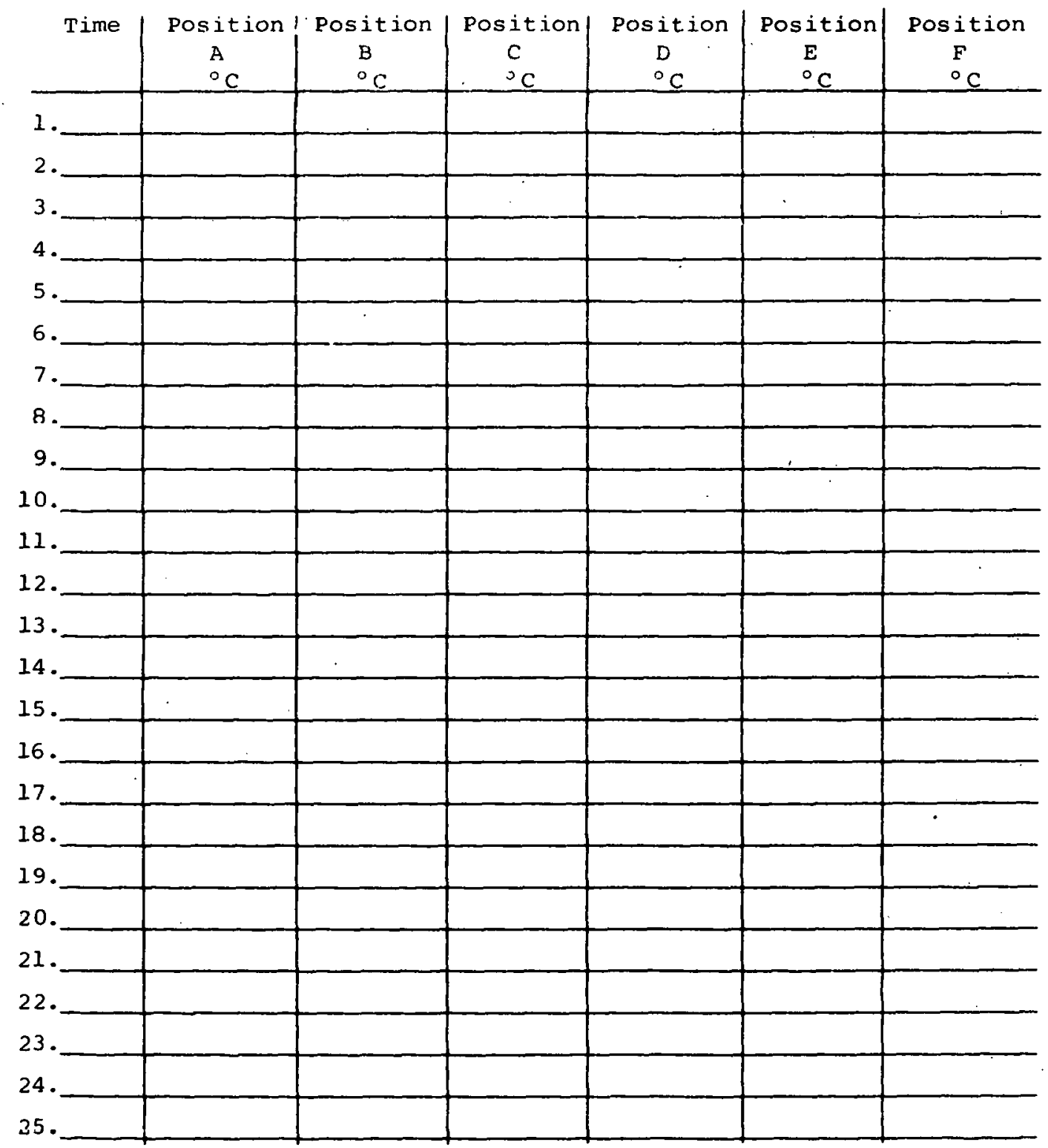

Position A: North End - Operations Level

Position B: South End - Operations Level

Position C: East End - Experimental Level

Position D: West End - Experimental Level

Position E: East End - Equipumert Level

Position F: West End - Equipment Level 
DATA SHEET NO. 3

BUILDING LEAK TEST - DRY BULB \& WET BULB READINGS

Date:

Operator:

\begin{tabular}{|c|c|c|c|c|c|c|}
\hline Time & $\begin{array}{c}\text { Position } 1 \\
\mathrm{DB} / \mathrm{WB} \\
\circ \mathrm{F}\end{array}$ & $\begin{array}{c}\text { Position } 2 \\
\mathrm{DB} / \mathrm{WB} \\
{ }^{\circ} \mathrm{F}\end{array}$ & $\mid \begin{array}{c}\text { Position } 3 \\
\mathrm{DB} / \mathrm{WB} \\
{ }^{\circ} \mathrm{F}\end{array}$ & $\mid \begin{array}{c}\text { Position } \\
\mathrm{DB} / \mathrm{WB} \\
\circ \mathrm{F}\end{array}$ & $\begin{array}{c}\text { Position } \\
\mathrm{DB} / \mathrm{WB} \\
0 \mathrm{~F}\end{array}$ & $5 \begin{array}{c}\text { Position } 6 \\
\mathrm{DB} / \mathrm{WB} \\
0 \mathrm{~F}\end{array}$ \\
\hline 1. & 1 & $L$ & $L$ & $\angle$ & $\angle$ & 1 \\
\hline 2. & $\angle$ & $\angle$ & $\angle$ & $\angle$ & 1 & 1 \\
\hline 3. & 1 & $L$ & 1 & $L$ & 1 & $\angle$ \\
\hline 4 & 1 & 1 & 1 & 1 & 1 & 1 \\
\hline 5. & 1 & 1 & 1 & 1 & 1 & 1 \\
\hline 6. & 1 & 1 & 1 & 1 & $\angle$ & 1 \\
\hline 7. & $L$ & 1 & 1 & 1 & 1 & $\angle$ \\
\hline 8. & 1 & 1 & $\angle$ & 1 & 1 & 1 \\
\hline 9. & 1 & 1 & 1 & $L$ & 1 & 1 \\
\hline 10. & $\angle$ & 1 & 1 & $\angle$ & 1 & 1 \\
\hline 11. & 1 & 1 & 1 & 1 & 1 & $\angle$ \\
\hline 12. & 1 & 1 & 1 & 1 & 1 & 1 \\
\hline 13. & 1 & 1 & 1 & 1 & 1 & 1 \\
\hline 14. & 1 & 1 & 1 & 1 & 1 & 1 \\
\hline 15. & 1 & 1 & 1 & 1 & 1 & 1 \\
\hline 16. & 1 & 1 & 1 & 1 & 1 & 1 \\
\hline 17. & $\angle$ & 1 & 1 & 1 & 1 & 1 \\
\hline 18. & 1 & 1 & 1 & 1 & 1 & 1 \\
\hline 19. & 1 & 1 & 1 & 1 & 1 & 1 \\
\hline 20. & 1 & 1 & 1 & 1 & 1 & 1 \\
\hline 21. & 1 & 1 & 1 & 1 & 1 & 1 \\
\hline 22. & 1 & 1 & 1 & 1 & 1 & 1 \\
\hline 23. & 1 & 1 & 1 & 1 & 1 & 1 \\
\hline 24. & 1 & 1 & 1 & 1 & 1 & 1 \\
\hline 25. & 1 & 1 & 1 & 1 & 1 & 1 \\
\hline
\end{tabular}

\footnotetext{
Position 1: East Pile Face - Operations Level

Position 2: West Pile Face - Operations Level

Position 3: East Pile Face - Experimental Level

Position 4: West Pile Face - Experimental Level

Position 5; East Pile Face - Equipment Level

Position 6: West Pile Face - Equipment Level
} 
BUILDING LEAK TEST - CONTAINMENT VOLUME TEMPERATURE READINGS

Date:

Operator:

\begin{tabular}{|c|c|c|c|c|c|c|}
\hline Time & $\begin{array}{c}\text { Position } \\
7 \\
{ }^{\circ} \mathrm{C}\end{array}$ & $\begin{array}{c}\text { Position } \\
8 \\
{ }^{\circ} \mathrm{C}\end{array}$ & $\begin{array}{c}\text { Position } \\
9 \\
0 \mathrm{C}\end{array}$ & $\begin{array}{c}\text { Position } \\
10 \\
0\end{array}$ & $\begin{array}{c}\text { Position } \\
11 \\
{ }^{\circ} \mathrm{C}\end{array}$ & $\begin{array}{c}\text { Position } \\
12 \\
{ }^{\circ} \mathrm{C}\end{array}$ \\
\hline 1. & & & & & & \\
\hline 2. & & & & & & \\
\hline 3. & & & & & & \\
\hline 4. & & & & & & \\
\hline 5. & & & & & & \\
\hline 6. & & & & & & . \\
\hline 7. & & & & & & \\
\hline 8. & & & & & & \\
\hline 9. & & & & & & \\
\hline 10. & & & & & & \\
\hline 11. & & & & & & \\
\hline 12. & & & & & & \\
\hline 13. & & & & & & \\
\hline 14. & & . & & & & \\
\hline 15. & & & & & & \\
\hline 16 & & & & & $\cdot$ & \\
\hline 17. & & & & & & \\
\hline 18. & & & & & & \\
\hline 19. & & & & & & \\
\hline 20.1 & & & & & & \\
\hline 21. & & & & & & \\
\hline 22 & & & & & & \\
\hline 23 & $\theta$ & & & & & \\
\hline 24 & & & & & & \\
\hline 25 . & & & & & & \\
\hline
\end{tabular}

Position 7: North Stairway - Operations Level

Position 8: South Stairway - Operations Level

Position 9: North Stairway - Experimental Level

Position 10: South Stairway - Experimental Level

Position 11: North Stairway - Equipment Level

Position 12: South Stairway - Equipment Level 


\section{BROOKHAVEN NATIONAL LABORATORY}

MEMORANDUM

DATE : $6-18-64$

TO: J. M. Hendrie

FROM: L. G. Epel

SUBJECT: Tentative HFBR Building Leak Test Procedure and Error Analysis

\section{INTRODUCTION}

The HFBR containment building, including four air locks, encompasses $1.73 \times 10^{6}$ cubic feet of volume. The design stipulates that this volume shall leak no more than $1 \%$ per day when the pressure in the building is 2 psi above the pressure outside the building. In the Safety Analysis Report a leakage value of 5\% of building volume per day at 2 psi overpressure was used in evaluating the effects of the Maximum Credible Accident.

Experimental values of the leak rate will be obtained by pressurizing the building with a blower and then observing the pressure degradation in the sealed building as a function of time. The pressure swing over a given time interval can be translated into a leak rate by utilization of the gas laws. This memorandum will give a description of the building leak test and present the expected error in the leakage measurement for two measuring techniques; the absolute method and the reference volume method.

\section{DESCRIPTION OF EOUIPMENT}

The containment building will be pressurized by means of a blower permanently installed in the north receiving room, together with appropriate valving and piping. The blower characteristics are given in Figure 1 .

Also located in the receiving room are three differential manometers having a fluid with a specific gravity of 2.95 and having subdivisions reading directly in fifths of an inch of water. The first manometer indicates the pressure difference between a "reference volume" and the containment volume. The second manometer indicates the pressure difference between the 
reference volume and the outside atmosphere and the third manometer indicates the pressure difference between the containment volume and the outside atmosphere. The "reference volume" is a leak tight system constructed of copper piping and tubing located on all three levels of the building and having volumes on each level in proportion to the containment volume attributable to that level.

Other equipment includes a mercury barometer for measuring atmospheric pressure, a number of thermometers to measure temperatures in the reference volume as well as in the containment volume, sling psychrometers for relative humidity determinations in the building, and a pressure-stat that can be set to break the circuit delivering power to the blower motor at any desired building pressure up to about $5 \mathrm{psig.} \mathrm{In} \mathrm{addition,} \mathrm{there} \mathrm{are}$ about twenty strain gages attached to the building dome and to two of the bolts anchoring the dome to the concrete pad; these will be monitored during the test.

\section{GENERAL PROCEDURE}

In the first few tests the building will be only moderately pressurized, say to about 1 psig, to allow personnel to locate and eliminate leaks. In the final tests the design pressure of 2 psig will be attained. When the desired pressure is reached in the building the blower will be shut off and the building allowed to leak. Periodic observations of the barometric reading, the manometer readings, the thermometers, psychrometers and strain gages will be made throughout the test. This can be done with the inner air lock doors open or shut, thereby including or excluding the four air lock volumes. The duration of the test should allow for a few percent of volume leakage so that the determination of this percentage is not rendered meaningless by the inherent error resulting from deviations in measuring the various physical variables. This time interval is anticipated to be about 24 hours. :

In the error analysis that follows, as in other sections of this memorandum, we are concerned with the total leakage, occurring over an unspecified time interval, and due to a variable overpressure. This total leakage can be prorated to some nominal overpressure (e.g. $2 \mathrm{psig})$ and then converted to a leak rate by dividing by the appropriate time interval of the test. Thus the total leakage, which is the directly derived quantity, is converted to a figure bearing more usual units, such as "percent of building volume per day at 2 psig" or "fraction of building volume per second at 2 psig". It is important to remember that 
the error in leakage that is derived in the next section is scaled. in the same manner as the leakage when this conversion is made and hence these two entities retain their relative magnitudes with respect to one another.

\section{ERROR ANALYSIS}

Absolute Method. If the subscript 1 denotes conditions at the beginning of the test and the subscript 2 denotes conditions at the end of the test, we have from the gas laws that

$$
\begin{aligned}
& \mathrm{w}_{1}=\left(\mathrm{p}_{\mathrm{ml}}-\mathrm{p}_{\mathrm{v} 1}\right) \mathrm{v} / \mathrm{RT}_{1} \\
& \mathrm{w}_{2}=\left(\mathrm{p}_{\mathrm{m} 2}-\mathrm{p}_{\mathrm{v} 2}\right) \mathrm{v} / \mathrm{RT}_{2}
\end{aligned}
$$

where

$$
\begin{aligned}
& \mathrm{p}_{\mathrm{m}}=\text { measured pressure in containment volume } \\
& \mathrm{P}_{\mathrm{v}}=\text { partial pressure of water vapor } \\
& \mathrm{V}=\text { containment building volume } \\
& \mathrm{R}=\text { gas constant for air } \\
& \mathrm{T}=\text { temperature in containment volume }
\end{aligned}
$$

Combining Eq. (1) and (2) into the definition of the leakage, $I$, we have

$$
L=\frac{w_{1}-w_{2}}{w_{1}}=1-\frac{T_{1}}{T_{2}} \frac{p_{m} 2-p_{v l}}{p_{m l}-p_{v l}}
$$

The error in the leakage determination due to errors in the measured quantities is obtained by retaining the linear terms of a Taylor series expansion about the mean value of each of the independent variables

$$
\begin{aligned}
\Delta L= & \frac{\partial L}{\partial T_{1}} \Delta T_{1}+\frac{\partial L}{\partial T_{2}} \Delta T_{2}+\frac{\partial L}{\partial p_{m l}} \Delta p_{m l}+\frac{\partial L}{\partial p_{m 2}} \Delta p_{m 2} \\
& +\frac{\partial L}{\partial P_{v l}} \Delta p_{v l}+\frac{\partial L}{\partial p_{v 2}} \Delta p_{v 2}
\end{aligned}
$$

where the partial derivatives are evaluated at the mean value of 
the explicit variables. The derivatives can be thought of as coefficients that influence the effect of the errors made in reading the independent variables on the final value of leakage. They are shown in Table I for each of the six variables, both in general terms and numerically for $1 \%$ leakage and $5 \%$ leakage. The numerical values in the table are based on initial and final temperatures of $75^{\circ} \mathrm{F}$, an initial total pressure of $16.696 \mathrm{psi}$, and an initial and final water vapor pressure of .2149 psi, corresponding to $50 \%$ relative humidity.

Table I - Influence Coefficients for Absolute Method

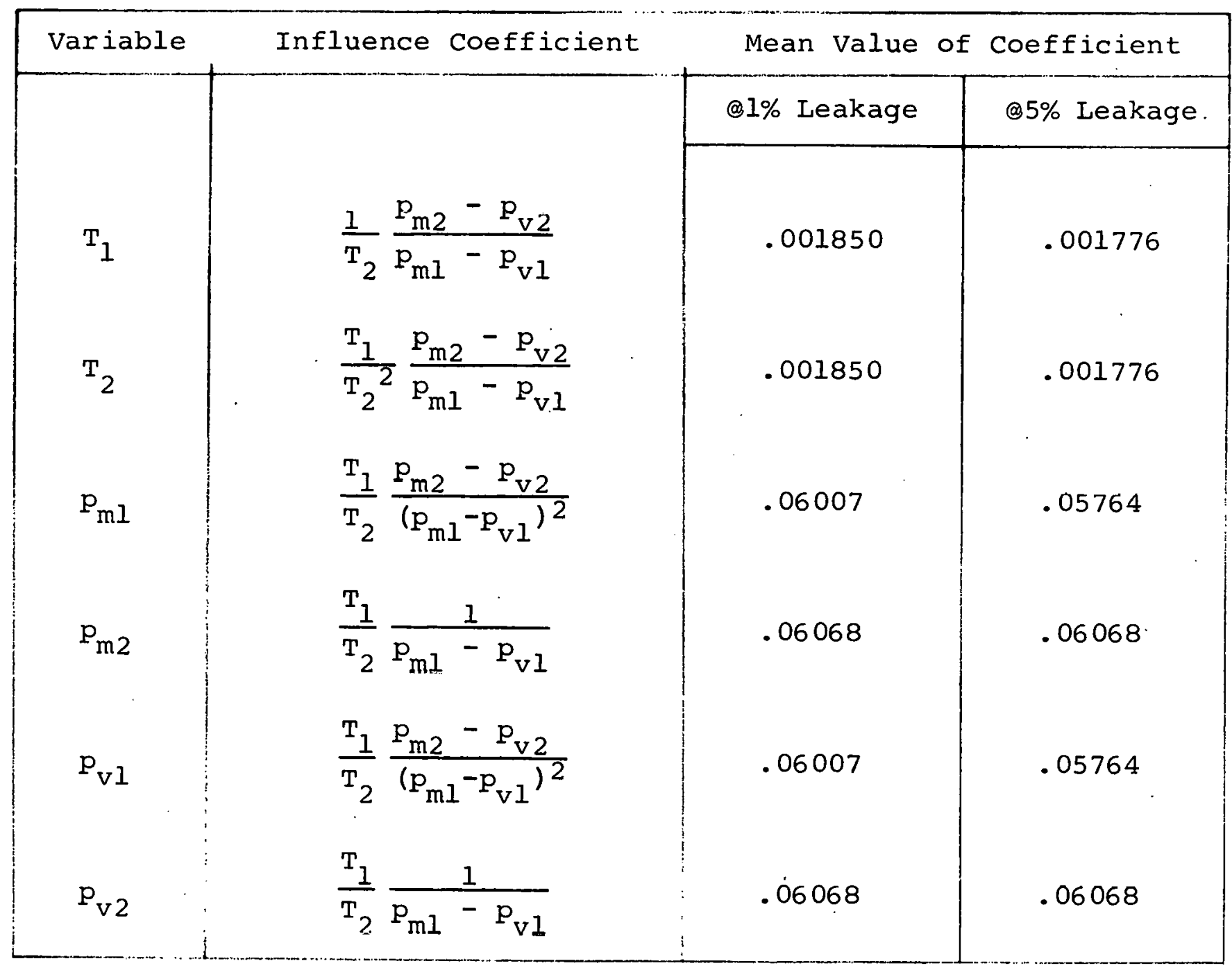

In Table II the six independent variables are assigned a reasonable value of expected error and the contribution of this error to the error in leakage determination is shown for both $1 \%$ and $5 \%$ leakage. 
Table II - Error Contributions of Independent Variables (Absolute Method)

\begin{tabular}{|c|c|c|c|}
\hline Variable & \multicolumn{1}{|c|}{ Expected Error } & Contribution to Leakage Error \\
\hline & & $01 \%$ Leakage & @5\% Leakage \\
\hline$T_{1}$ & $2^{\circ} \mathrm{R}$ & .003700 & .003552 \\
$\mathrm{~T}_{2}$ & $2^{\circ} \mathrm{R}$ & .003700 & .003552 \\
$\mathrm{P}_{\mathrm{m} 1}$ & $.05 \mathrm{psi}$ & .003004 & .002882 \\
$\mathrm{P}_{\mathrm{m} 2}$ & $.05 \mathrm{psi}$ & .003034 & .003034 \\
$\mathrm{P}_{\mathrm{v} 1}$ & $.03 \mathrm{psi}$ & .001802 & .001729 \\
$\mathrm{P}_{\mathrm{v} 2}$ & $.03 \mathrm{psi}$ & .001820 & .001820 \\
\hline
\end{tabular}

Thus it is seen that for representative values of, and reasonable errors for the independent variables, the error in calculating the leakage is about $1.7 \%$; $i . e$. typical values of test results would be $1 \pm 1.7 \%$ leakage or $5 \pm 1.7 \%$ leakage.

Reference Volume Method. The error in leakage determination can be reduced by use of the reference volume method in which the pressure change in the containment building due to leakage is sensed by comparing the containment pressure to a "reference volume" pressure rather than measuring it absolutely. If a differential manometer is arranged to measure the difference between reference volume and containment volume total pressure, $\Delta \mathrm{P}_{\mathrm{m}}$, and if the air in the reference volume is essentially dry, we can write

$$
\Delta p_{m}=p_{r}-p_{m}=p_{r}-\left(p+p_{v}\right)
$$

where the subscript "r" refers to the reference volume and the unsubscripted $p$ in parenthesis is the partial pressure of air in the containment volume. Using Eq. (5) in conjunction with the gas 
laws we write the expression for leakage as

$$
L=\frac{w_{1}-w_{2}}{w_{1}}=\frac{\left(p_{r 1}-p_{v 1}-\Delta p_{m 1}\right)-\frac{T_{1}}{T_{2}}\left(p_{r 2}-p_{v 2}-\Delta p_{m 2}\right)}{p_{m 1}-p_{v l}}
$$

$$
\text { But } p_{r 2}=\frac{T_{r 2}}{T_{r 1}} p_{r 1} \quad \text { and it can be }
$$

shown* that $\mathrm{T}_{r 1}=\mathrm{T}_{1}$ and $\mathrm{T}_{\mathrm{r} 2}=\mathrm{T}_{2}$ so that $\mathrm{Eq}$. (6) can be recast into

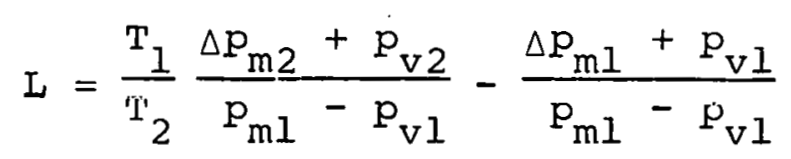

Equation (7) expresses the leakage in terms of seven independent parameters, eliminating $\mathrm{p}_{\mathrm{m} 2}$ but adding $\Delta \mathrm{p}_{\mathrm{ml}}$ and $\Delta \mathrm{P}_{\mathrm{m} 2}$ to the set of variables obtained in the absolute method.

If we now form the Taylor series for Eq. (7) analogous to Eq. (4) we can find the influence coefficients as before; they are listed in Table III. It will be noted from Table III that some of the values of influence coefficients depend on $\Delta \mathrm{p}_{\mathrm{ml}}$ and/or $\Delta \mathrm{p}_{\mathrm{m} 2}$ and not simply on their difference (which relates to the leakage). Since $\Delta p_{m l}$ is arbitrary (the original pressure difference between reference volume and containment volume can be varied to suit) the numerical value of some of the influence coefficients will also be arbitrary. In general, the smaller the magnitude of $\Delta \mathrm{p}_{\mathrm{ml}}$ (and hence also the magnitude of $\Delta \mathrm{p}_{\mathrm{m} 2}$ ) for a given test, the smaller will be the error in the leakage. For Table III the value of $\Delta \mathrm{p}_{\mathrm{ml}}$ chosen was $1 \mathrm{psi}$. This is reasonable for the conditions anticipated during the test and the range of the manometers that will be used. The values used for the other variables were the same as for the absolute system analysis.

*E. G. Keshock \& C. E. DeBogdan, "Leak-Rate Testing of the NASA Plum Brook Reactor Containment Vessel", NASA TN D-1731, July 1963. 
Table III - Influence Coefficients for Reference volume Method

\begin{tabular}{|c|c|c|c|}
\hline Variable & Influence Coefficient & \multicolumn{2}{|c|}{ Mean value of coefficient } \\
\hline & & @1\% Leakage & $@ 5 \%$ Leakage \\
\hline $\mathrm{T}_{1}$ & $\frac{1}{T_{2}} \frac{\Delta P_{m 2}+p_{v 2}}{p_{m 1}-p_{v 1}}$ & $1.56510^{-4}$ & $2.31210^{-4}$ \\
\hline $\mathrm{T}_{2}$ & $\frac{\mathrm{T}_{1}}{\mathrm{~T}_{2}{ }^{2}} \frac{\Delta \mathrm{p}_{\mathrm{m} 2}+\mathrm{p}_{\mathrm{v} 2}}{\mathrm{P}_{\mathrm{m} 1}-\mathrm{P}_{\mathrm{v} 1}}$ & $1.56510^{-4}$ & $2.31210^{-4}$ \\
\hline $\mathrm{p}_{\mathrm{ml}}$ & $\frac{\mathrm{T}_{1}\left(\Delta \mathrm{p}_{\mathrm{m} 2}+\mathrm{p}_{\mathrm{v} 2}\right)-\mathrm{T}_{2}\left(\Delta \mathrm{p}_{\mathrm{ml}}+\mathrm{p}_{\mathrm{vl}}\right)}{\mathrm{T}_{2}\left(\mathrm{p}_{\mathrm{ml}}-\mathrm{p}_{\mathrm{vl}}\right)^{2}}$ & $6.068 \quad 10^{-4}$ & $3.03410^{-3}$ \\
\hline$p_{v 1}$ & $\frac{\mathrm{T}_{1}\left(\Delta \mathrm{p}_{\mathrm{m} 2}+\mathrm{p}_{\mathrm{v} 2}\right)-\mathrm{T}_{2}\left(\Delta \mathrm{p}_{\mathrm{ml}}+\mathrm{p}_{\mathrm{ml}}\right)}{\mathrm{T}_{2}\left(\mathrm{p}_{\mathrm{ml}}-\mathrm{p}_{\mathrm{vl}}\right)^{2}}$ & $6.007 \quad 10^{-2}$ & $5.764 \quad 10^{-2}$ \\
\hline $\mathrm{p}_{\mathrm{v} 2}$ & $\frac{T_{1}}{T_{2}} \frac{1}{P_{m l}-p_{v l}}$ & $6.06810^{-2}$ & $6.06810^{-2}$ \\
\hline$\Delta \mathrm{P}_{\mathrm{m} 1}$ & $\frac{1}{p_{m l}-p_{v l}}$ & $6.06810^{-2}$ & $6.068 \quad 10^{-2}$ \\
\hline$\Delta \mathrm{p}_{\mathrm{m} 2}$ & $\frac{T_{1}}{T_{2}} \frac{1}{p_{m 1}-p_{v 1}}$ & $6.06810^{-2}$ & $6.068 \quad 10^{-2}$ \\
\hline
\end{tabular}

In Table IV the influence coefficients from Table III are used together with the expected errors of the independent variables to find the error in the leakage. The error chosen for $\Delta \mathrm{P}_{\mathrm{ml}}$ and $\Delta \mathrm{p}_{\mathrm{m} 2}$ was $.005 \mathrm{psi}$; the errors for the other parameters were taken to be the same as before.

It is evident that the expected error in leakage will be about $1 / 2 \%$; i.e. results would typically be $1 \pm .5 \%$ leakage or $5 \pm .5 \%$ leakage. This represents a considerable improvement over the possible error inherent in the absolute method. Further, it is seen that about $3 / 4$ of the error in the reference volume method 
is due to the error contributed by the water vapor partial pressure uncertainty. It seems improbable that the error in measuring this variable can be decreased substantially, although under favorable temperature-humidity conditions in the building this error may be halved.

Table IV - Error Contributions of Independent Variables (Reference Volume Method)

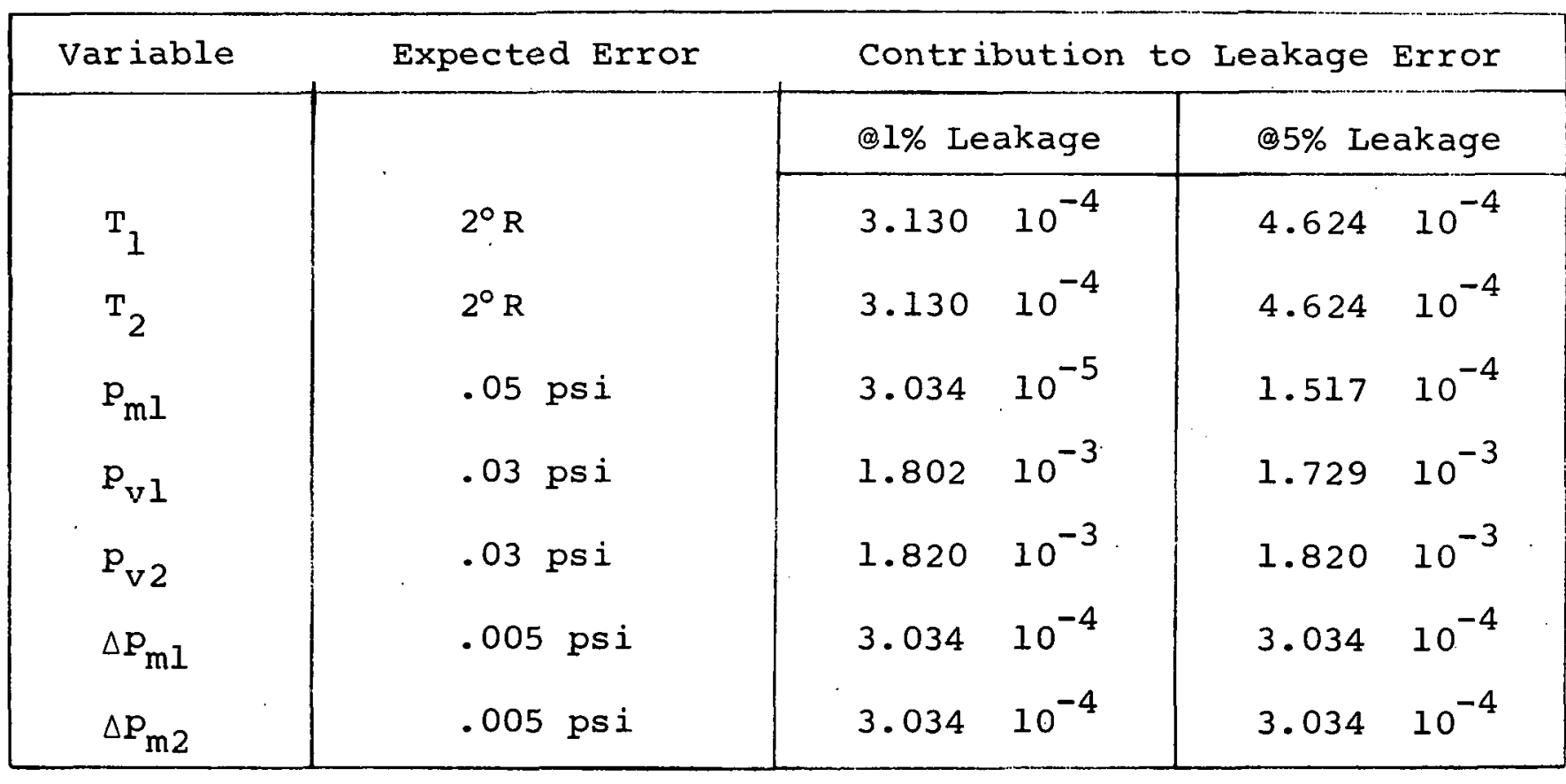

Total Error .004867 .005232

\section{CONCLUSIONS}

Reasonable results can be expected from a building leak test that continues long enough for a few percent of building volume to leak. The reference volume method yields an error in leakage of about one half percent while the absolute method results in an error three or four times this amount. The absolute method is therefore judged to be inadequate.for the final leakage determination since the inherent error in this method is about as large as the value being investigated.

LGE : ps

CC: HFBR Distribution 
359.5G KEUFFEL \& ESSER CO

MADE in U.S.A
Mo to the inch

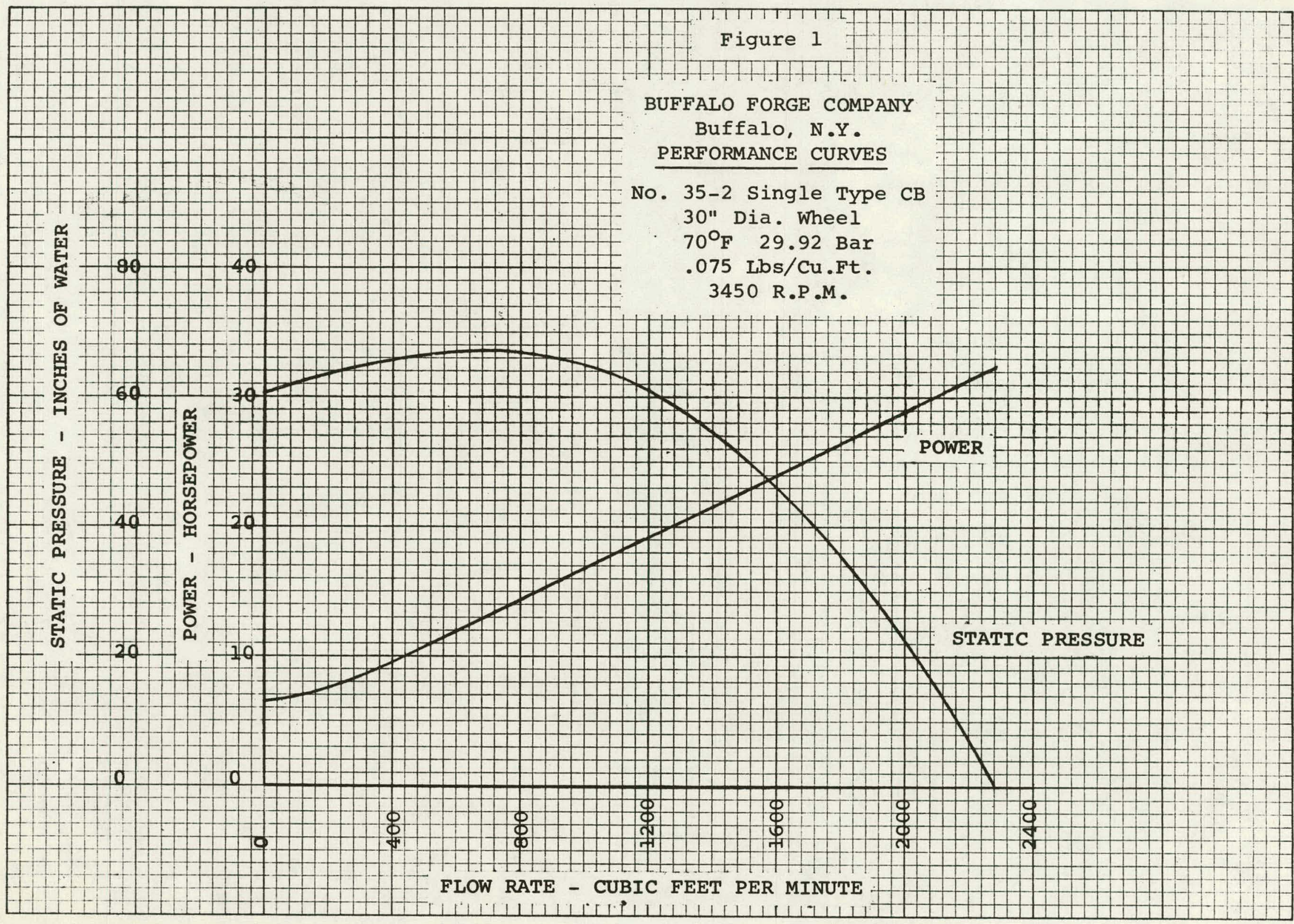

